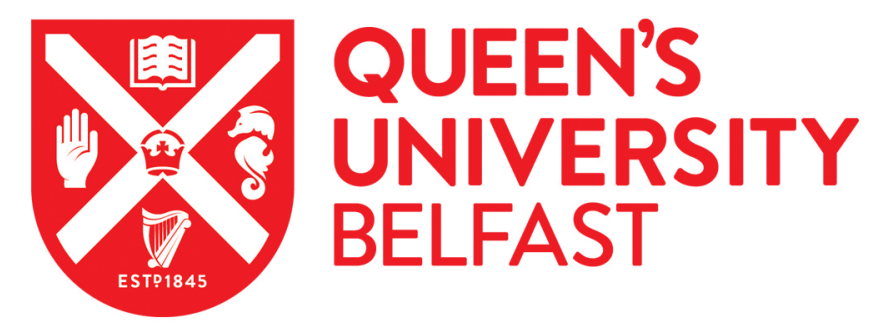

\title{
Photocarcinogenic risk of narrowband ultraviolet B (TL-01) photography: early follow-up data
}

Black, R. J., \& Gavin, A. (2006). Photocarcinogenic risk of narrowband ultraviolet B (TL-01) photography: early follow-up data. British Journal of Dermatology, 154(3), 551-577. https://doi.org/10.1111/j.13652133.2005.07085.x

\section{Published in:}

British Journal of Dermatology

Queen's University Belfast - Research Portal:

Link to publication record in Queen's University Belfast Research Portal

\section{General rights}

Copyright for the publications made accessible via the Queen's University Belfast Research Portal is retained by the author(s) and / or other copyright owners and it is a condition of accessing these publications that users recognise and abide by the legal requirements associated with these rights.

Take down policy

The Research Portal is Queen's institutional repository that provides access to Queen's research output. Every effort has been made to ensure that content in the Research Portal does not infringe any person's rights, or applicable UK laws. If you discover content in the Research Portal that you believe breaches copyright or violates any law, please contact openaccess@qub.ac.uk. 
with DH have gluten-sensitive enteropathy and the rash responds to gluten withdrawal. ${ }^{1}$

While awaiting review the patient independently began the Atkins' diet. ${ }^{2}$ The DH completely resolved within 4 weeks. She remained on the Atkins' diet for 9 months, and for the whole of this period her skin remained absolutely clear. After this time, with dietician supervision, she transferred to a gluten-free diet. The patient remains on the gluten-free diet and has been completely asymptomatic for the last 3 years.

The Atkins' diet advocates unlimited protein and fat intake, with restricted carbohydrate intake. In the longer-term maintenance phase, the diet remains low in cereal grains (wheat, rye and barley), and is therefore low in gluten. There are no previous reports of DH resolving with the Atkins' diet, although three patients have recently been described who, on discontinuing the Atkins' diet, subsequently developed biopsy-proven coelic disease with positive antiendomysial antibodies. $^{3}$

Department of Dermatology, Leicester Royal Infirmary,

M.J. SLAdDEN Leicester LE1 5WW, U.K.

G.A. JOHNSTON

E-mail: m.sladden@doctors.org.uk

\section{References}

1 Reunala T. Dermatitis herpetiformis: coeliac disease of the skin. Ann Med 1998; 30:416-18.

2 Atkins R. Dr Atkins' New Diet Revolution. New York: Simon \& Schuster, 1998.

3 van Heel DA, Dart J, Nichols S et al. Novel presentation of coeliac disease after following the Atkins' low carbohydrate diet. Gut 2005; 54:1342.

Conflicts of interest: none declared.

\section{Photocarcinogenic risk of narrowband ultraviolet B (TL-01) phototherapy: early follow-up data}

\section{DOI: $10.1111 / j .1365-2133.2005 .07085 . x$}

SIR, We read with interest the article by Man et al. ${ }^{1}$ following on from their original notification. ${ }^{2}$ We too have recently compared all patients treated with narrowband ultraviolet UVB (TL-01) in the dermatology department of Craigavon Area Hospital (a large regional hospital in Northern Ireland) against the Northern Ireland Cancer Registry. Since 1993, 484 patients have received at least one course of TL-01 UVB (a course being $\approx 18$ treatments) for a variety of skin disorders including psoriasis, eczema and polymorphic light eruption, the majority being for psoriasis. Levels of cancer in these patients were verified by the Northern Ireland Cancer Registry, a 'population-based registry ( 1.7 million) which receives data
Table 1 Rates of skin cancer in Northern Ireland (2002)

\begin{tabular}{lcc}
\hline & Males & Females \\
\hline Malignant melanoma (ICD-10 C43) & & \\
$\quad$ Crude rate per 100 000 & $11 \cdot 6$ & $15 \cdot 9$ \\
$\quad$ European age-standardized rate per 100 000 & $11 \cdot 8$ & $14 \cdot 8$ \\
Nonmelanoma skin cancer (ICD-10 C44) & & \\
$\quad$ Crude rate per 100 000 & $155 \cdot 8$ & $126 \cdot 3$ \\
European age-standardized rate per 100 000 & $156 \cdot 6$ & $95 \cdot 7$ \\
\hline
\end{tabular}

electronically from multiple sources including all pathologically diagnosed skin cancers'.

Levels of cancer in the cohort of patients were as expected for rates in the general population. Four patients were found who cross-referenced with the register; of these none had developed skin cancer although one patient was identified who had received TL-01 UVB as treatment for pre-existing mycosis fungoides. The three remaining cases were unrelated: two cases of carcinoma in situ of the cervix and one hydatidiform mole of pregnancy. Both conditions were present before TL-01 UVB therapy. The rates of skin cancer in Northern Ireland (figures obtained from the Northern Ireland Cancer Registry) are shown in Table 1.

Another smaller study from Germany ${ }^{3}$ also compared 192 patients treated with TL-01 UVB against their local cancer registry and again found no increase in skin cancer. While the numbers in our study are larger than those from Germany ${ }^{3}$ but smaller than those in Scotland ${ }^{1}$ it is reassuring that no cases of skin cancer have been found as our population has a high percentage of skin types I and II ( $\approx 92 \%)$. Skin types in the Scottish group were mainly types I-III but skin types were not recorded in the German study.

However, in our study some of the patients had also received psoralen plus UVA therapy and these had been excluded in the German and Scottish studies. It could be postulated that if there were an interaction between these some cases of skin cancer might have been expected. TL-01 UVB would therefore appear to be a relatively safe treatment modality at present, although continued long-term follow-up is still required.

Department of Dermatology,

R.J. BLACK Craigavon Area Hospital, A.T. GAVIN * Portadown BT63 5QQ, U.K.

*Northern Ireland Cancer Registry,

Queen's University Belfast,

Mulhouse Building, Belfast BT12 6BJ, U.K.

E-mail: drrjblack@cahgt.n-i.nhs.uk

\section{References}

1 Man I, Crombie IK, Dawe RS et al. The photocarcinogenic risk of narrowband UVB (TL-01) phototherapy: early follow-up data. Br J Dermatol 2005; 152:755-7. 
2 Man I, Crombie IK, Dawe RS, Ferguson J. The photocarcinogenic risk of narrowband TL-01 ultraviolet B phototherapy: early followup data. Br J Dermatol 2003; 149 (Suppl. 64): 12 (Abstr.).

3 Weischer M, Blum A, Eberhard F et al. No evidence for increased skin cancer risk in psoriasis patients treated with broadband or narrowband UVB phototherapy; a first retrospective study. Acta Derm Venereol (Stockh) 2004; 84:370-4.

Conflicts of interest: none declared.

\section{Fumaric acid esters in psoriasis}

$$
\text { DOI: } 10.1111 / j .1365-2133.2005 .07103 . x
$$

SIR, We read with great interest the article by Harries et al. ${ }^{1}$ The authors present their data on the efficacy and tolerability of fumaric acid esters (FAE) in 58 patients with severe psoriasis. A similar study was recently conducted in our department and we would like briefly to present our first encouraging findings on this interesting topic and to comment on some of the issues raised.

Eleven patients who had received FAE for psoriasis between November 2002 and November 2004 were identified from our pharmacy records. Their medical notes were reviewed retrospectively. Patients were treated with FAE in tablet form using two formulations differing in strength: (i) low-strength tablets supplied as Fumaderm Initial, containing $30 \mathrm{mg}$ dimethylfumarate, $67 \mathrm{mg}$ monoethylfumarate Ca salt, $5 \mathrm{mg}$ monoethylfumarate $\mathrm{Mg}$ salt and $3 \mathrm{mg}$ monoethylfumarate $\mathrm{Zn}$ salt, and (ii) high-strength tablets supplied as Fumaderm, containing $120 \mathrm{mg}$ dimethylfumarate, $87 \mathrm{mg}$ monoethylfumarate $\mathrm{Ca}$ salt, $5 \mathrm{mg}$ monoethylfumarate $\mathrm{Mg}$ salt and $3 \mathrm{mg}$ monoethylfumarate $\mathrm{Zn}$ salt. The dose of the FAE was adjusted according to the regimen derived from the published guidelines. $^{2}$

Eleven patients (five men and six women), age range 19-59 years (mean 43) participated in our study. The majority had chronic plaque psoriasis (73\%) and the rest (27\%) guttate psoriasis. The mean duration of the psoriasis prior to FAE treatment was 20 years (range 4-40). Ten of the 11 patients (91\%) had previously received photochemotherapy $(\mathrm{n}=10)$ and ultraviolet $\mathrm{B}$ phototherapy $(\mathrm{n}=10)$. Nine of the 11 patients $(82 \%)$ had received other systemic therapies for psoriasis, with $67 \%$ having received two or more agents. Methotrexate $(n=4)$, ciclosporin $(\mathrm{n}=5)$, hydroxycarbamide $(\mathrm{n}=1)$ and acitretin $(n=6)$ were the most commonly used drugs. These agents had either failed to clear the psoriasis or had resulted in significant side-effects. FAE were used as a monotherapy in all our patients.

Nine patients $(82 \%)$ showed improvement in their psoriasis, compared with the $55 \%$ improvement rate quoted by Harries et al. Five patients (45\%) cleared completely, compared with the $17 \%$ clearance rate quoted by Harries et al. There was no improvement in two (18\%) patients and none of our patients showed any deterioration. The mean duration from beginning of treatment to initial improvement was 5.6 weeks (range 3-8) with the mean time to clearance being 5.5 months (range 4-9).

Evaluation of our patients' improvement was based on clinical examination alone. Although the Psoriasis Area and Severity Index has a defined role in the assessment of psoriatic patients in clinical trials, we believe it is subjective, complicated and too time-consuming to be used in most clinical settings.

Three patients $(27 \%)$ discontinued treatment after a mean period of 5.7 months (range 1 week to 16 months). The main reasons for discontinuation of treatment were sideeffects $(n=2)$, lack of efficacy $(n=1)$ and lack of compliance $(\mathrm{n}=1)$.

Side-effects were seen in all our patients. Gastrointestinal complaints were the most common side-effect (82\%), varying from mild stomach upsets (82\%) to stomach cramps (45\%) and diarrhoea $(27 \%)$. We, overall, agree with the authors ${ }^{1}$ that all the above side-effects appear to be dose related and settle with time. Flushing was the second most common sideeffect, reported by two (18\%) patients. Lymphocytopenia (defined as lymphocyte count $<1.5 \times 10^{9} \mathrm{~L}^{-1}$ ) developed during treatment in six $(54 \%)$ patients. In one patient the value fell to $<0.5 \times 10^{9} \mathrm{~L}^{-1}$ after 10 months of FAE treatment. The correlation between lymphocytopenia and a beneficial response to FAE, as observed by Harries et al., is of great interest and was also noted in our study. All patients who developed lymphocytopenia showed improvement or clearance of their disease. A transient eosinophilia was noticed in three of 11 patients (27\%), 4 weeks after commencement of treatment. It lasted for a mean period of 2.5 months (range $2-3)$. No significant abnormalities were noted in renal or liver function.

Our retrospective analysis indicates that FAE treatment of psoriasis is effective and safe, and is tolerated well by patients. Psoriasis is a troublesome and occasionally debilitating condition and, although there are various well-established therapeutic options, none of them is without significant side-effects.

FAE therapy is a relatively new option for psoriatic patients in the U.K. There are still many questions to be answered regarding its use. The few British studies suggest that FAE treatment is safe, with few side-effects, reasonable cost and satisfactory results. More randomized controlled trials are required before we can start using FAE as a first-line systemic antipsoriatic agent. A new product (BG-12-oral fumarate), which contains only one fumaric acid ester and which appears to produce fewer gastrointestinal symptoms, is currently undergoing clinical trials.

Department of Dermatology,

Z. FIKA

Glan Clwyd, Rhyl,

Denbighshire LL18 5UJ, U.K.

R.E.A. Williams

E-mail: zoifika@hotmail.com

D.J. Williamson 